\title{
Restriction endonuclease variation in the region of the alcohol dehydrogenase gene: a comparison of null and normal alleles from natural populations of Drosophila melanogaster
}

\author{
Chengshan Jiang, \\ John B. Gibson, \\ Ann V. Wilks and \\ Allan L. Freeth
}

\author{
Population Genetics Group, Research School of \\ Biological Sciences, The Australian National \\ University, P.O. Box 475, Canberra City, A.C.T. 2601, \\ Australia.
}

The restriction endonuclease variation in the $12 \mathrm{~kb}$ region surrounding twelve $A d h$ null alleles extracted from three Tasmanian populations has been compared with normal alleles from the same populations. Each of the null alleles had the same haplotype as revealed by digestions with eight hexanucleotide restriction enzymes. This haplotype also occurred in 4 of the 46 chromosomes bearing normal alleles which were tested; these four chromosomes with the null allele haplotype carried the $A d h^{S}$ allele. The data suggest that the $A d h$ null alleles from geographically separate populations share a common ancestry and are derived from the same mutation in an $\mathrm{Adh}^{\mathrm{S}}$ allele.

\section{INTRODUCTION}

The average frequencies of null activity alleles at loci encoding enzymes in natural populations are generally reported to be less than 0.3 per cent (Voelker et al., 1980; Langley et al., 1981; Allendorf et al., 1981) except where the loci are duplicated and then very much higher frequencies are commonplace (Freeth, 1986). The discovery of unexpectedly high frequencies (up to 3.9 per cent) of null alleles at the single alcohol dehydrogenase locus (Adh) in some Australian populations of Drosophila melanogaster (Freeth and Gibson, 1985) prompted questions about the origins of the alleles and their maintenance in natural populations.

The $A d h$ null alleles were found in geographically separate populations and persisted over years within populations (Freeth and Gibson, 1985). Analyses of the biochemical properties of $20 \mathrm{Adh}$ null alleles extracted from four Tasmanian populations showed that, although the $A d h$ gene was intact, they did not produce alcohol dehydrogenase $(\mathrm{ADH})$ activity and, of those tested, all were CRM negative (Freeth, Gibson and de Couet, 1986). The biochemical data did not provide any evidence for heterogeneity in properties between separately extracted $A d h$ null alleles, although the homozygous viabilities of second chromosomes bearing the alleles varied from lethal to normal.

Any attempt to explain the relatively high frequencies of null alleles must take account of the number of different alleles that are present in the populations. Whilst the molecular identities of alleles with similar properties can be gauged from their DNA sequences, variation in the molecular landscape surrounding a locus can be assessed with restriction endonuclease mapping and used to derive the ancestry of specific gene mutations. This approach has been successfully applied in human populations to trace the origins of $\beta$ thalassaemia variants (Antonarakis et al., 1982; Orlein et al., 1982), sickle cell haemoglobin genes (Pagnier et al., 1984), serum albumin variation (Murray et al., 1984) and $\alpha$-antitrypsin deficiency alleles (Cox et al., 1985).

To provide some indication of the heterogeneity and relatedness of the $A d h$ null alleles we have used restriction endonucleases to map a $12 \mathrm{~kb}$ region including the $A d h$ locus in samples of second chromosomes bearing null and normal alleles. These data have been used to test whether the molecular landscape surrounding the $A d h$ null activity alleles differs from that of normal 
alleles and to compare null alleles extracted from different populations, and in different years, to assess their molecular similarities.

\section{MATERIALS AND METHODS}

\section{Populations sampled and extraction of second chromosomes}

The 58 second chromosomes bearing $A d h$ alleles used in these experiments were extracted from three of the Tasmanian populations of $D$. melanogaster described by Freeth and Gibson (1985). Two of the populations, Cygnet and Huonville II (Avondale Farm) are about $13 \mathrm{~km}$ apart in the south of the island and the third, Tamar (Marian's Vineyard in the Tamar valley), is $300 \mathrm{~km}$ to the north. Between the northern and southern fruit growing regions of Tasmania there are few natural Drosophila habitats and attempts to collect D. melanogaster in the central region of the island were unsuccessful, although populations were expected to occur associated with human settlements.

The Cygnet and Tamar populations were sampled in 1984 by setting up single female lines ( 75 for Cygnet and 82 for Tamar) and extracting second chromosomes bearing normal $A d h$ alleles (one from each line) using $\mathrm{CyO}$ (Lindsley and Grell, 1968) as a balancer (see Freeth and Gibson, 1985). The Huonville II population was sampled in 1985 and the second chromosomes were extrac- ted by crossing a male from a single female line to females heterozygous for $\mathrm{CyO}$ and a deficiency covering the $A d h$ locus, $D f(2 L) 64 j$, (Lindsley and Grell, 1968), then backcrossing a single $+/ D f(2 L) 64 j$ male to $C y O / D f(2 L) 64 j$ females to establish a $+/ D f(2 L) 64 j$ line.

The methods used to detect putative $A d h$ null alleles in the Cygnet and Tamar samples followed the technique of Voelker et al. (1980) modified to avoid dysgenic phenomena (Freeth and Gibson, 1985). From the flies collected at Huonville II in 1985, 185 single female lines were screened by classifying their progenies into $\mathrm{ADH}$ phenotypes (see Freeth and Gibson, 1985). Abnormal segregation patterns in seven of the lines suggested the presence of null alleles and these were isolated. In addition two null alleles ( $\mathrm{H} 36$ and $\mathrm{H} 41)$ had been extracted from the Huonville II population sampled in 1984. The frequencies of $A d h$ null alleles in the three populations were 0.4 per cent (Cygnet, 1984), 3.2 per cent (Huonville II, 1984), 1.88 per cent (Huonville II, 1985) and 0.5 per cent (Tamar, 1984). The 12 null alleles used in this study (one from Cygnet, three from Tamar, two from Huonville II in 1984 and six in 1985) were isolated either by using $C y O$ as a balancer or by exposing the F2 progenies of single female lines to 1-penten3-ol vapour (Sofer and Hatkoff, 1972) and isolating the surviving flies, which are homozygous for an Adh null allele.

The numbers of normal $A d h$ alleles investigated from each population are given in tables 1 ,

Table 1 Restriction endonuclease map haplotypes in the Tamar population. In this and the following two tables the extracted chromosomes are ordered according to the ADH electrophoretic phenotype to aid comparisons

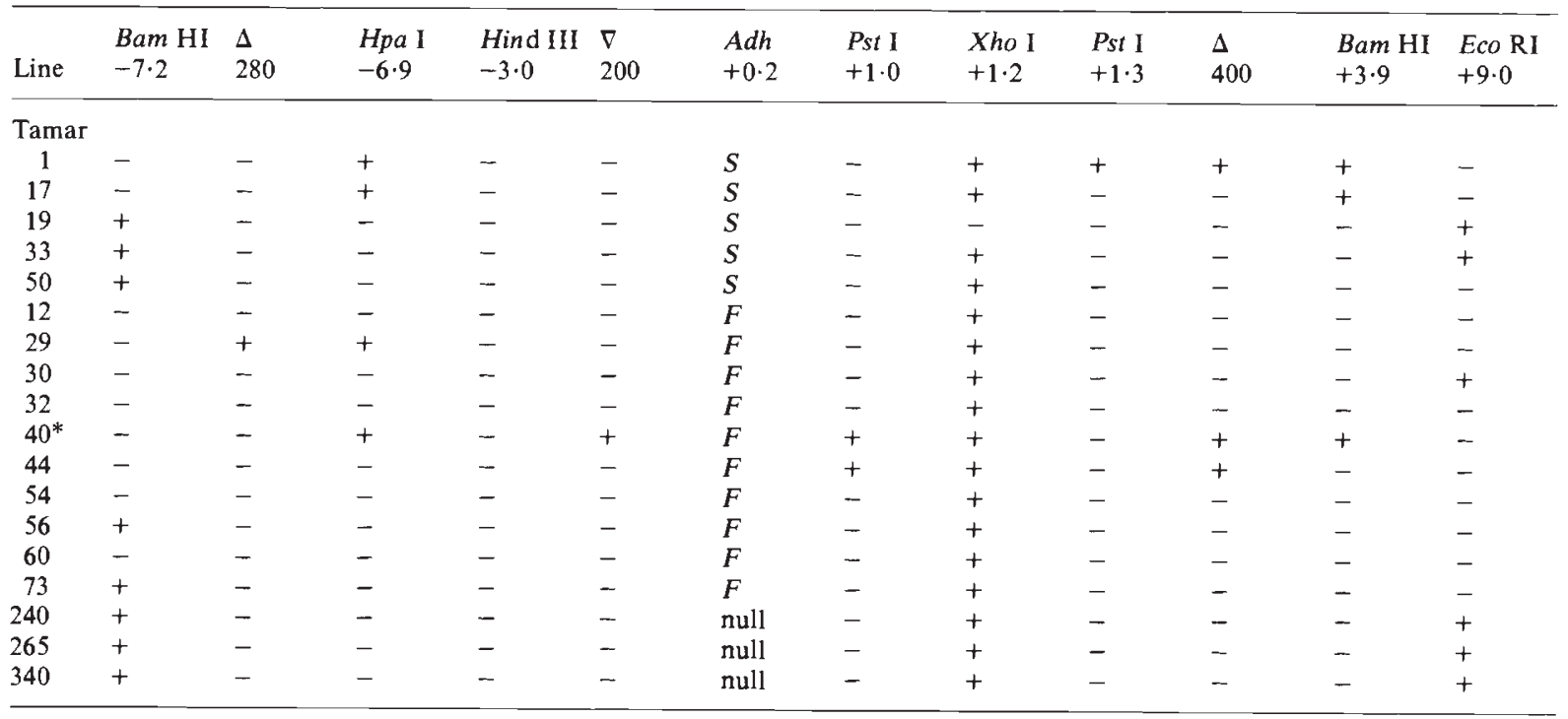

* The Tamar 40 chromosome has a complex structure, see p. 104. 
Table 2 Restriction endonuclease map haplotypes in the Cygnet population

\begin{tabular}{|c|c|c|c|c|c|c|c|c|c|c|c|c|}
\hline Line & $\begin{array}{l}\text { Bam HI } \\
-7 \cdot 2\end{array}$ & $\begin{array}{l}\Delta \\
280\end{array}$ & $\begin{array}{l}\text { Hpa I } \\
-6.9\end{array}$ & $\begin{array}{l}\text { Hind III } \\
-3 \cdot 0\end{array}$ & $\begin{array}{l}\nabla \\
200\end{array}$ & $\begin{array}{l}\text { Adh } \\
+0 \cdot 2\end{array}$ & $\begin{array}{l}\text { Pst I } \\
+1 \cdot 0\end{array}$ & $\begin{array}{l}\text { Xho I } \\
+1 \cdot 2\end{array}$ & $\begin{array}{l}\text { Pst I } \\
+1 \cdot 3\end{array}$ & $\begin{array}{l}\Delta \\
400\end{array}$ & $\begin{array}{l}\text { Bam HI } \\
+3.9\end{array}$ & $\begin{array}{l}\text { Eco RI } \\
+9 \cdot 0\end{array}$ \\
\hline \multicolumn{13}{|c|}{ Cygnet } \\
\hline 3 & + & + & - & - & - & $S$ & - & + & - & - & - & - \\
\hline 8 & - & - & - & - & - & $S$ & - & - & + & $\begin{array}{ll}- \\
-\end{array}$ & - & + \\
\hline 19 & + & - & - & - & - & $S$ & - & + & - & - & - & + \\
\hline 25 & + & - & - & - & - & $S$ & - & + & - & - & - & + \\
\hline 28 & - & - & + & - & - & $S$ & - & + & - & - & - & - \\
\hline 45 & - & - & - & - & - & $S$ & - & + & - & - & - & - \\
\hline 61 & + & - & - & - & - & $S$ & - & - & - & - & - & - \\
\hline 72 & - & - & - & - & - & $S$ & - & + & - & - & - & - \\
\hline 5 & + & - & - & + & + & $F$ & - & + & - & - & - & - \\
\hline 11 & + & - & - & - & - & $F$ & - & + & - & - & - & - \\
\hline 20 & - & - & - & - & - & $F$ & - & + & - & - & - & - \\
\hline 29 & - & - & - & + & + & $F$ & - & + & - & - & - & - \\
\hline 33 & - & - & - & - & + & $F$ & - & + & - & + & - & - \\
\hline 35 & - & - & - & + & + & $F$ & - & + & - & - & - & - \\
\hline 51 & - & - & - & - & - & $F$ & - & + & - & & - & + \\
\hline 95 & + & - & - & - & - & null & - & + & - & - & - & + \\
\hline
\end{tabular}

2 and 3; the alleles were taken at random from those available from the chromosome extractions.

\section{ADH electrophoresis}

The electrophoretic ADH phenotypes of flies homozygous or hemizygous for extracted $A d h$ alleles were assessed on cellulose acetate mem- branes stained for alcohol dehydrogenase activity as described by Wilks et al. (1980).

Table 3 Restriction endonuclease map haplotypes in the Huonville II population

\begin{tabular}{|c|c|c|c|c|c|c|c|c|c|c|c|c|}
\hline Line & $\begin{array}{l}\text { Bam HI } \\
-7 \cdot 2\end{array}$ & $\begin{array}{l}\Delta \\
280\end{array}$ & $\begin{array}{l}\text { Hpa I } \\
-6.9\end{array}$ & $\begin{array}{l}\text { Hind III } \\
-3 \cdot 0\end{array}$ & $\begin{array}{l}\nabla \\
200\end{array}$ & $\begin{array}{l}\text { Adh } \\
+0.2\end{array}$ & $\begin{array}{l}\text { Pst I } \\
+1 \cdot 0\end{array}$ & $\begin{array}{l}\text { Xho I } \\
+1 \cdot 2\end{array}$ & $\begin{array}{l}\text { Pst I } \\
+1 \cdot 3\end{array}$ & $\begin{array}{l}\Delta \\
400\end{array}$ & $\begin{array}{l}\text { Bam HI } \\
+3.9\end{array}$ & $\begin{array}{l}\text { Eco R1 } \\
+9 \cdot 0\end{array}$ \\
\hline \multicolumn{13}{|c|}{ Huonville II } \\
\hline 8 & - & - & - & - & - & $S$ & - & + & - & - & - & - \\
\hline 10 & - & - & - & - & - & $S$ & - & + & - & - & - & - \\
\hline 13 & - & - & - & - & - & $S$ & - & + & - & - & - & - \\
\hline 18 & + & - & - & - & - & $S$ & - & + & - & - & - & - \\
\hline 16 & + & - & - & - & - & $S$ & - & + & - & - & - & + \\
\hline 14 & - & - & - & - & - & $S$ & - & + & - & - & - & - \\
\hline 3 & - & - & - & - & + & $F$ & - & + & - & - & - & + \\
\hline 4 & - & - & - & - & - & $F$ & - & + & - & - & - & - \\
\hline 5 & - & - & - & + & + & $F$ & - & + & - & - & - & - \\
\hline 6 & - & - & - & + & + & $F$ & - & + & - & - & - & - \\
\hline 7 & - & - & - & - & - & $F$ & - & + & - & - & - & - \\
\hline 9 & - & - & - & + & + & $F$ & - & + & - & - & - & - \\
\hline 12 & - & - & - & - & - & $F$ & - & + & - & - & - & + \\
\hline 15 & - & - & - & + & + & $F$ & - & + & - & - & - & - \\
\hline 17 & - & - & - & - & - & $F$ & - & + & - & - & - & + \\
\hline 19 & - & - & - & + & + & $F$ & - & + & - & - & - & - \\
\hline 98 & + & - & - & - & - & null & - & + & - & - & - & + \\
\hline 70 & + & - & - & - & - & null & - & + & - & - & - & + \\
\hline 144 & + & - & - & - & - & null & - & + & - & - & - & + \\
\hline 9 & + & - & - & - & - & null & - & + & - & - & - & + \\
\hline $77 *$ & + & - & - & - & - & null & - & + & - & - & - & + \\
\hline $52 \dagger$ & + & - & - & - & - & null & - & + & - & - & - & + \\
\hline $36 \ddagger$ & + & - & - & - & - & null & - & + & - & - & - & + \\
\hline $41 \dagger \ddagger$ & + & - & - & - & - & null & - & + & - & - & - & + \\
\hline
\end{tabular}

* Homozygous lethal chromosome

$†$ Homozygotes sterile

¥ Extracted in 1984 whereas all other chromosomes in this population were extracted in 1985 
that whole flies were used. The Huonville II DNA samples were also prepared from whole adults, but using the method of Chia et al. (1985). Adult flies for DNA extractions were aged for at least 4 days and then deyeasted for 2 hours prior to freezing in liquid nitrogen and storage at $-70^{\circ} \mathrm{C}$.

\section{Restriction endonuclease digests and electrophoresis of DNA}

DNA prepared from stocks of each of the fiftyeight extracted $A d h$ alleles was digested using hexanucleotide restriction endonucleases under buffer conditions suggested by the manufacturers (Amersham). The eight enzymes used in the survey were Eco R1, Hind III, Sal I, Xho I, Pst I, Bam HI, Xba I and Hpa I. These particular enzymes were chosen because each had previously been shown to reveal variation in the $A d h$ region in other populations (Langley et al., 1982; Birley, 1984). Electrophoresis of the digests was carried out at about $2 \mathrm{~V} / \mathrm{cm}$ for $16-19 \mathrm{hrs}$ at room temperature in a horizontal gel apparatus with 1.0 per cent agarose gels prepared in buffer containing $0 \cdot 04 \mathrm{M}$ Tris $\mathrm{HCl}, p \mathrm{H} 7 \cdot 8,5 \mathrm{mM}$ sodium acetate and $1 \mathrm{mM}$ EDTA.

\section{Hybridisation}

DNA fragments were transferred from agarose gels to nitrocellulose filters as described by Southern
(1975). Prehybridization of the filters was carried out as described by Miklos et al. (1984). The sAF-2 plasmid (Goldberg, 1980), which includes within an $11.5 \mathrm{~kb}$ insert the coding sequence of the $D$. melanogaster Adh gene together with $10 \mathrm{~kb}$ of flanking DNA, was labelled with $\left[\alpha-{ }^{32} \mathrm{P}\right]-d \mathrm{CTP}$ by nick translation (Rigby et al., 1977). Autoradiography was carried out at $-70^{\circ} \mathrm{C}$ on Kodak film (XRP-1) using intensifying screens.

\section{RESULTS}

The total restriction endonuclease varation detected in the three Tasmanian populations is shown in fig. 1; the variation between $A d h$ alleles from each population is listed in tables 1,2 and 3 . Following previous studies on restriction maps of the $A d h$ region we have assigned the coordinate $\mathrm{O}$ to the invariant Bam HI site in the second exon of Adh (Chia et al., 1985). The electrophoretic phenotypes, ADH-S and ADH-F, of the normal activity alleles are indicated.

Overall six of the eight enzymes (Bam HI, Hind III, Hpa I, Pst I, Xho I and Eco RI) exhibited restriction endonuclease site recognition variation due to the presence or absence of the recognition sites. Two insertions (of $280 \mathrm{bp}$ and $400 \mathrm{bp}$ ) and one deletion (200 bp) were also detected. In total 11 different map variants were found although not all were present in each popu-
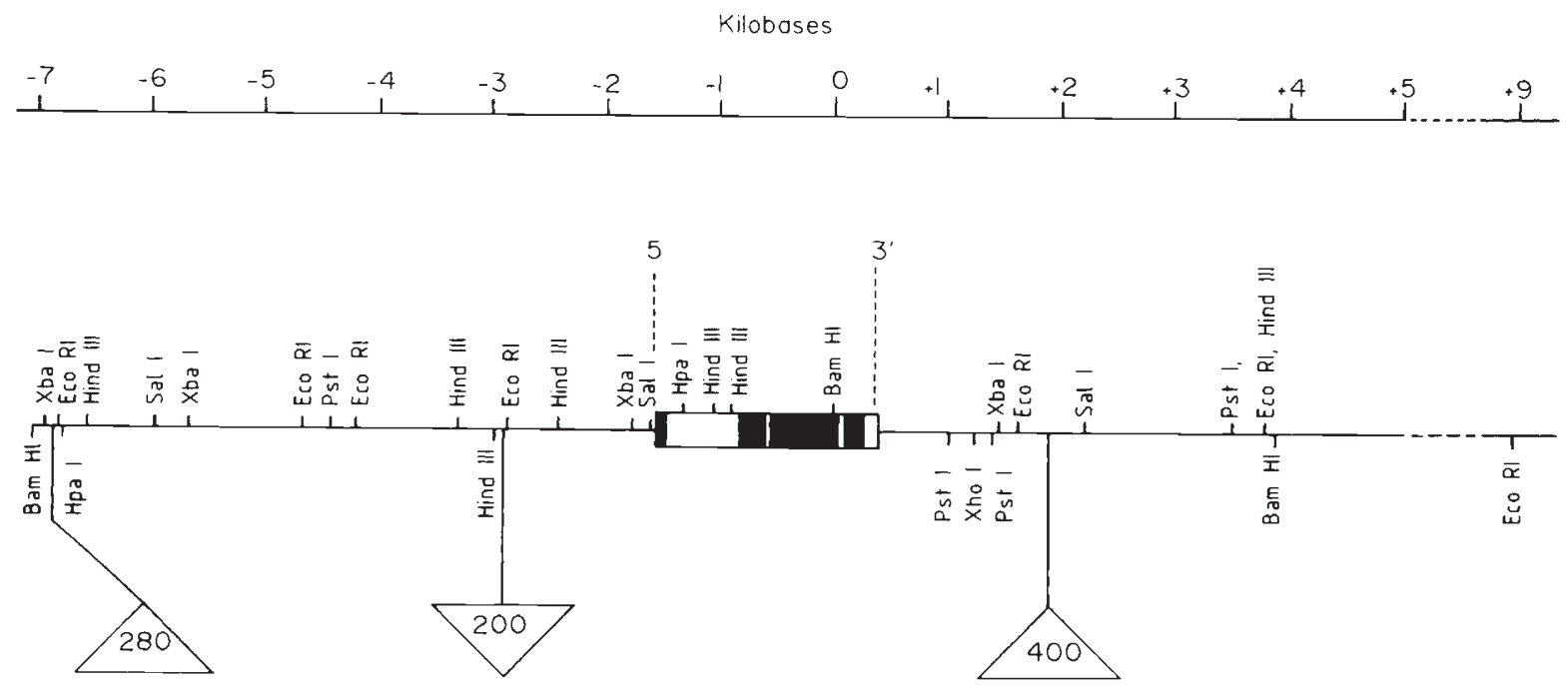

Figure 1 Restriction endonuclease map variation detected in the $A d h$ region of three Tasmanian populations. $3^{\prime}$ is to the right of the figure. The boundaries of the $A d h$ transcription unit are indicated and the adult $5^{\prime}$ leader and three exons are shaded. Variable restriction endonuclease sites are indicated below the map; triangles represent insertions (points upward) or deletions (points downward) and the estimated sizes are shown. The Eco RI site $(+9 \cdot 0)$ was outside the probed region but could be scored unambiguously in all populations. 
lation. For example, the Hind III $(-3 \cdot 0)$ site was not found in Tamar and the Pst $\mathrm{I}(+1 \cdot 0)$ and Bam HI (+3.9) sites were absent from Cygnet and Huonville II. An analysis of the frequencies of the 11 restriction map variants in chromosomes bearing normal $A d h$ alleles shows that the Cygnet and Huonville II samples do not differ from each other $\left(\chi_{10}^{2}=13.94, p>0.05\right)$ but they do differ from Tamar $\left(\chi_{10}^{2}=18 \cdot 69, p<0 \cdot 05\right.$, and $\chi_{10}^{2}=36 \cdot 4, p<$ 0.001 , respectively).

Of the 58 chromosomes investigated all except one had the expected single copy of the Adh gene and flanking DNA. Tamar 40 was exceptional in that the region which hybridised to the sAF 2 clone was $16 \mathrm{~kb}$. This chromosome is being analysed in detail but it appears that a duplicate of the region between $-6 \cdot 2$ and $-3 \cdot 2$ is inserted at $+5 \cdot 2$ and a duplicate of the region from $-1 \cdot 2$ to 0 , which includes part of the $A d h$ coding region, is inserted at $+4 \cdot 0$.

The tabulations show that although 14 different haplotypes occurred, each of the twelve $A d h$ null bearing chromosomes had the same haplotype, regardless of the population from which they were derived. It is noteworthy that the null allele haplotype does not include either of the two insertions or the deletion detected in the Tasmania populations.

Inspection of the data reveals that in the Tamar sample the three null alleles share the haplotype of one normal $A d h$ allele, Tamar 33. In the Cygnet samples two chromosomes, Cygnet 19 and 25, and in Huonville II one chromosome, Huonville 16, have the haplotype of the null allele. Each of these four chromosomes carries the $A d h^{S}$ allele.

Amongst the chromosomes carrying normal $A d h$ alleles there was also some significant gametic disequilibria in each population (table 4). The same three disequilibria were present in Cygnet and Huonville II, but none of these were significant in Tamar.

\section{DISCUSSION}

The overall level of restriction endonuclease variation in the Adh region of the Tasmanian populations is similar to that previously described for this gene region in other populations of $D$. melanogaster (Cross and Birley, 1986; Aquadro et al., 1986). In particular the estimates of overall heterozygosity (Nei and Tajima, 1981) (table 5) are very similar to those reported by Cross and Birley (1986) for the Australian Chateau Tahbilk population which is located on the mainland $525 \mathrm{~km}$ north of Tamar. Amongst chromosomes bearing normal $A d h$ alleles there was significant heterogeneity between the Tasmanian populations with Cygnet and Huonville II differing from Tamar in the frequencies of the eleven restriction map variants and in the patterns of gametic disequilibria. However, the proportion of polymorphic nucleotide sites, $\hat{p}$ (Hudson, 1982), and the estimated heterozygosity per nucleotide pair, $\hat{\theta}$ (Ewens, Spielman and Harris, 1981), were each significantly lower $(p<0.05)$ in Huonville II than in Cygnet or Tamar (table 5). Elsewhere we will compare the $A d h$ restriction map variation in the Tasmanian populations with similar data we have collected for a number of mainland populations spanning 30 degrees of latitude along the $A d h^{S}$ cline described by Wilks et al. (1980).

The main aim, however, of the experiments described here was to investigate the molecular landscape surrounding the $A d h$ locus in a sample of separately isolated null activity alleles so that they could be compared with one another and with

Table 4 Significant gametic disequilibria in the Tasmanian populations

\begin{tabular}{|c|c|c|}
\hline Population & $\begin{array}{l}\text { Number of } \\
\text { comparisons }\end{array}$ & Significant gametic disequilibria \\
\hline Tamar & 55 & $\begin{array}{l}\text { Bam HI }(-7.2): \text { Adh, } p<0.01 \\
\text { Hpa I }(-6.9): \text { Bam HI }(+3.9), p<0.01 \\
\text { Adh }(+0.2): \text { Bam HI }(+3.9), p<0.01 \\
\text { Pst I }(+1 \cdot 0): \Delta 400, p<0.01 \\
\text { Xho I }(+1 \cdot 2): \text { Eco RI }(+9.0), p<0.05\end{array}$ \\
\hline Cygnet & 45 & $\begin{array}{l}\text { Hind III }(-3 \cdot 0): \text { Adh }, p<0.05 \\
\text { Hind III }(-3 \cdot 0): \nabla 200, p<0.001 \\
\nabla 200: A d h(+0.2), p<0.05\end{array}$ \\
\hline Huonville II & 10 & $\begin{array}{l}\text { Hind III }(-3.0): \text { Adh }, p<0.05 \\
\text { Hind III }(-3.0): \nabla 200, p<0.001 \\
\nabla 200: \operatorname{Adh}(+0.2), p<0.05\end{array}$ \\
\hline
\end{tabular}


Table 5 Estimates of the proportion of polymorphic nucleotides, $\hat{p}$, overall heterozygosity, $h$ (Nei and Tajima, 1981) and estimated heterozygosity per nucleotide pair, $\hat{\theta}$ (Ewens, Spielman and Harris, 1981). Standard errors are given in parentheses and that for $\theta$ assumes free recombination

\begin{tabular}{lccc}
\hline Population & $\hat{p}$ & $\hat{h}$ & $\hat{\theta}$ \\
\hline Tamar & 0.019 & 0.86 & 0.007 \\
& $(0.007)$ & $(0.057)$ & $(0.0026)$ \\
Cygnet & 0.017 & 0.95 & 0.006 \\
& $(0.007)$ & $(0.014)$ & $(0.0024)$ \\
Huonville II & 0.009 & 0.85 & 0.003 \\
& $(0.004)$ & $(0.06)$ & $(0.0015)$ \\
\hline
\end{tabular}

normal alleles from the same populations. The results show that, regardless of the population or year of origin, each of the $12 A d h$ null alleles has the same haplotype as revealed by the 8 hexanucleotide restriction endonucleases we have used. The data for the Huonville II and Tamar populations are particularly revealing as 8 and 3 null alleles respectively were available for comparison with normal alleles. Amongst the normal Adh alleles the null allele haplotype occurred at a frequency of 0.07 in each population yet all three Tamar nulls were identical $(p<0.001)$, as were the eight null alleles from Huonville II $(p<0.001)$.

It is significant that the null alleles do not contain any insertions or deletions in the size range which could be resolved with the technique used (greater than $50 \mathrm{bp}$ ). This observation eliminates the possibility that the loss of ADH activity and the relatively high frequency of null alleles were brought about by the insertion of a mobile element of this size in, or close to, the $A d h$ gene. In this context it is also worth mentioning that attempts to use $P$ element insertion to induce mutations at the $A d h$ locus have not been successful (Kidwell, 1986).

The data described here strongly suggest that the $A d h$ regions of the separately extracted null alleles from the Tasmanian populations share a common ancestry, which implies that the null alleles may well be multiple copies of the same mutation. A possible, but in our view unlikely, alternative hypothesis which cannot be discounted with the present data, is that the null alleles derive from multiple mutations at an $A d h$ allele in a specific molecular landscape. If this were so it might be expected that the separate mutations would possibly differ in structure and in biochemical properties. The observation that all the nulls investigated here have been shown to produce mRNA's that are larger than normal, and all have similar biochemical properties, mitigates against this hypothesis (Freeth, 1986). Clearly, DNA sequence data from null alleles from the Tasmanian populations is required to fully test this possibility and to elucidate the molecular lesion leading to loss of ADH activity.

The observation that the four chromosomes which share the null allele haplotype all carry the $A d h^{S}$ allele suggests the mutation which resulted in the loss of ADH activity occurred in that allele. Again, the DNA sequence of a null allele will be required to confirm this suggestion. It is interesting that the frequency of $A d h^{S}$ is higher in the south of Tasmania than in the north (see data in Anderson and Gibson, 1985; in the samples used in the present study the $A d h^{S}$ frequencies were 0.45 in Cygnet, 0.42 in Huonville II and 0.15 in Tamar) whereas in Australasia as a whole the frequency of $A d h^{S}$ is highest in populations from the northern latitudes (Wilks et al., 1980).

If, as seems likely, the null alleles turn out to be multiple copies of the same mutant, then the null has increased in frequency and spread to populations (at least $300 \mathrm{~km}$ apart) which to some extent are genetically differentiated at the $A d h$ locus. Tests of the Huonville II population show that the null has persisted over at least 3 years and this population, in common with the other Tasmanian populations, experiences severe bottlenecks in the winter months. An Adh null allele has also been detected at the All Saints population in northern Victoria $(350 \mathrm{~km}$ north of the Bass Strait which is approximately $275 \mathrm{~km}$ wide and separates Tasmania from the mainland) but as this null was detected in a sample of frozen flies it could not be isolated (Freeth, 1986). It will be interesting to analyse null alleles from mainland populations to see whether they too share the same haplotype.

We have little evidence, as yet, to suggest why the null allele increased in frequency. Our estimates of the depression of heterozygote fitness, based on the average frequency of $A d h$ null alleles in Tasmania, is about 0.0003 (Freeth and Gibson, 1985). ADH activity is completely absent from the null homozygotes and the level in heterozygotes between the null allele and $A d h^{F}$ or $A d h^{S}$ is about half that in normal homozygotes (Freeth, Gibson and de Couet, 1986). This reduction is not trivial but in view of the data of Middleton and Kacser (1983) the difference may not be large enough to affect ethanol metabolism per se, although other reactions on which the enzyme impinges may be changed. There is evidence that heterozygotes between the nulls and normal alleles have a higher viability on ethanol media than expected from their ADH levels (Freeth, Gibson and de Couet, 1986). 
Future studies on the fitness and population distribution of the $A d h$ null alleles will be aided by the information that they are probably all copies of the same allele. By using tetra nucleotide endonucleases, detailed restriction maps of the cloned Adh null alleles can be constructed and should provide evidence on the origin of the alleles. The nucleotide divergence between alleles will give an indication of when the mutation occurred.

Acknowledgements We thank George Miklos and Jane Davies for helpful guidance with molecular techniques, David Goldberg for $A d h$ clones and prepublication information on the restriction maps and Ross Cunningham for statistical advice. C.J. acknowledges the financial support of the Department of Education of the People's Republic of China and an Australian National University Postgraduate Scholarship.

\section{REFERENCES}

ALLENDORF, F. W., KNUDSEN, K. L. AND BLAKE, G. M. 1982. Frequencies of null alleles at enzyme loci in natural populations of ponderosa and red pine. Genetics, 100, 497-504.

ANDERSON, D. G. AND GIBSON, J. B. 1985. Variation in alcohol dehydrogenase activity in vitro in flies from natural populations of Drosophila melanogaster. Genetica, 67, 13-19.

ANTONARAKIS, S. E., ORKIN, S. H., KAZAIAN, H. H., GOFF, S. C., BOEHM, C. D., WABER, D. G., SEXTON, J. P., OSTRER, H., FAIRBANKS, $\dot{V}$. F. AND CHAKRAVARTI, A. 1982. Evidence for multiple origins of the $\beta$-globin gene in South East Asia. Proc. Natl. Acad. Sci. USA, 79, 6608-6611.

AQUADRO, C. F., DEESE, S. F., BLAND, M. M., LANGLEY, C. F. AND LAURIE-AHLBERG, C. C. 1986. Molecular population genetics of the alcohol dehydrogenase gene region of Drosophila melanogaster. Genetics, 114, 1156-1190.

BIRLEY, A. J. 1984. Restriction endonuclease map variation and gene activity in the $\mathrm{ADH}$ region in a population of Drosophila melanogaster. Heredity, 52, 103-112.

CHIA, W., SAVAKIS, C., KARP, R., PELHAM, H. AND ASHBURner, M. 1985. Mutation of the $A d h$ gene of Drosophila melanogaster containing an internal tandem duplication. J. Mol. Biol., 186, 679-688.

COX, D. W., woo, S. L. C. AND MANSFIELD, T. 1985. DNA restriction fragments associated with $\alpha$-antitrypsin indicate a single origin for deficiency allele P12. Nature, 316, 79-81.

CROSS, S. R. H. AND BIRLEY, A. J. 1986. Restriction endonuclease map variation in the $A d h$ region in populations of Drosophila melanogaster. Biochem. Genet., 24, 415-433.

EWENS, W. J., SPIELMAN, R. S. AND HARRIS, H. 1981. Estimation of genetic variation at the DNA level from restriction endonuclease data. Proc. Natl. Acad. Sci. USA, 78, 37483750 .

FREETH, A. L. 1986. Ph.D. Dissertation, Australian National University, Canberra, A.C.T. Australia.

FREETH, A. L. AND GIBSON, J. B. 1985. Alcohol dehydrogenase and sn-glycerol-3-phosphate dehydrogenase null activity alleles in natural populations of Drosophila melanogaster. Heredity, 55, 369-374.

FREETH, A. L., GIBSON, J. B. AND DE COUET, H. G. 1986. The partial characterisation of alcohol dehydrogenase null alleles from natural populations of Drosophila melanogaster. Biochem. Genet., 24, 957-972.

GOLDBERG, D. A. 1980. Isolation and characterisation of the Drosophila alcohol dehydrogenase gene. Proc. Natl. Acad. Sci. U.S.A., 77, 5794-5798.

HUDSON, R. 1982. Estimating genetic variability with restriction endonucleases. Genetics, 100, 711-719.

KIDWELL, M. 1986. P-M mutagenesis. In Roberts, D. R. (ed.) Drosophila: A Practical Approach. IRL Press, Oxford, pp. 59-81.

LANGLEY, C. H., VOELKER, R. A., LEIGH BROWN, A. J., OHNISHI, S., DICKSON, B. AND MONTGOMERY, E. 1981. Null allele frequencies at allozyme loci in natural populations of Drosophila melanogaster. Genetics, 99, 151-156.

LINDSLEY, D. L. AND GRELL, E. H. 1968. Genetic variations of Drosophila melanogaster. Carn. Inst. Wash. Pub., Number 627.

MIDDLETON, R. J. AND KACSER, H. 1983. Enzyme variation, metabolic flux and fitness: alcohol dehydrogenase in Drosophila melanogaster. Genetics, 105, 663-650.

MIKLOS, G. L. G. 1984. The isolation of high molecular weight DNA from adult heads of D. melanogaster. Dros. Inf. Serv., $60,222-223$.

MIKLOS, G. L. G., HEALY, M. J., PAIN, P., HOWElls, A. J. AND RUSSELL, R. J. 1984. Molecular and genetic studies on the euchromatin-heterochromatin transition region of the $X$ chromosome of Drosophila melanogaster. I. A cloned entry point near to the uncoordinated (unc) locus. Chromosoma (Berl), 89, 218-227.

MURRAY, J. C., MILlS, K. A., DEMOPUlOS, C. M., HORNUNG, S. AND MOTULSKY, A. G. 1984. Linkage disequilibrium and evolutionary relationships of DNA variants (restriction enzyme fragment length polymorphisms) at the serum albumin locus. Proc. Natl. Acad. Sci. U.S.A., 81, 3486-3490.

NEI, M. AND TAJIMA, F. 1981. DNA polymorphism detectable by restriction endonucleases. Genetics, 97, 145-163.

ORKIN, S. H., KAZAZIAN, H. H., ANTONARAKIS, S. E., GOFF, S. C., BOEHM, C. D., SEXTON, J. P., WABER, P. G. AND GIARDINA, P. J. V. 1982. Linkage of $\beta$-thalassaemia muta tions and $\beta$-globin gene polymorphisms in human $\beta$-globin gene cluster. Nature, 296, 627-631.

PAGNIER, J., MEARS, J. G., DUNDA-BELKHODJA, O., SCHAEFFER-REGO, K. E., BELDJORD, C., NAGEL, R. L. AND LABIE, D. 1984. Evidence for the multicentric origin of the sickle cell haemoglobin gene in Africa. Proc. Natl. Acad. Sci. U.S.A., 81, 1771-1773.

RIGBY, P. W. J., DIECKMANN, M., RHODES, C. AND BERG, P 1977. Labelling DNA to high specific activity in vitro by nick translation with DNA polymerase I. J. Mol. Biol., 113, 237-251.

SOFER, W. H. AND HATKOFF, M. A. 1972. Chemical selection of alcohol dehydrogenase negative mutants in Drosophila. Genetics, 72, 545-549.

SOUTHERN, E. M. 1975. Detection of specific sequences among DNA fragments separated by gel electrophoresis. $J$. Mol. Biol., 98, 503-517.

VOELKER, R. A., LANGLEY, C. H., LEIGH BROWN, A. J., OHNISHI, S., DICKSON, B., MONTGOMERY, E. AND SMITH, S. C. 1980 . Enzyme null alleles in natural populations of Drosophila melanogaster: Frequencies in a North Carolina population. Proc. Natl. Acad. Sci. U.S.A., 77, 1091-1095.

WILKS, A. V., GIBSON, J. B., OAKESHOTT, J. G. AND CHAMBERS, C. K. 1980. An electrophoretically cryptic alcohol dehydrogenase variant in Drosophila melanogaster. II. Postelectrophoresis heat-treatment screening of natural populations. Aust. J. Biol. Sci., 33, 575-585. 